\title{
La eficiencia térmica de las mezclas de combustibles reciclados de aceites lubricantes y comestibles
}

\section{The thermal efficiency of recycled edible and lubricating oil fuel blends}

Marcos Gutiérrez

Tablet School-Escuela de Ciencias y Centro de Investigación Cientifica, Ecuador

Autor para correspondencia: marcosgutierrez@tablet-school.com

Fecha de recepción: 15 de agosto de 2018 - Fecha de aceptación: 01 de diciembre de 2018

\begin{abstract}
The energy demand increases with the social, industrial and technological requirements, independent of the sources to supply it. More than half of the total energy consumption is supplied by fossil fuels, which can be replaced by alternative and more environmentally friendly fuels. The present research evaluates thermal efficiency, net output work and energy availability from recycled vegetableanimal and synthetic-mineral substances, in a pure state and blended with neat diesel. The calculation uses mainly the heat value of each fuel and the air properties along each stroke of the diesel cycle. The purpose of the present research consists in the evaluation of the thermal efficiency of alternative fuels in functions of the whole engine cycle and not only Stoichiometric the heat value and quantity of each fuel. It was found that the neat fuel from recycled edible sources provides more net output work and is able to perform longer combustions, while the advantage of higher thermal efficiencies using recycled lubricating oil relies on its use as an additive in a blend with neat diesel. The use of alternative and ecological neat fuels of blends is conditioned by the efforts to produce them and by the resulting thermal efficiency, net output work and remaining energetic availability.
\end{abstract}

Key words: biodiesel; recycled lubricating oil; thermal efficiency; heat value; energetic availability

Resumen: La demanda energética aumenta con los requerimientos sociales, industriales y tecnológicos, independientemente de las fuentes para abastecerla. Más de la mitad del consumo total de energía es suministrado por combustibles fósiles, que pueden ser reemplazados por combustibles alternativos y más respetuosos con el medio ambiente. La presente investigación evalúa la eficiencia térmica, el trabajo de producción neta y la disponibilidad de energía a partir de sustancias vegetalesanimales y minerales sintéticos reciclados, en estado puro y mezclado con diesel puro. El cálculo utiliza principalmente el valor de calor de cada combustible y las propiedades del aire a lo largo de cada carrera del ciclo diesel. El propósito de la presente investigación consiste en evaluar la eficiencia térmica de los combustibles alternativos en las funciones de todo el ciclo del motor y no solo en estequiométrico el valor calorífico y la cantidad de cada combustible. Se encontró que el combustible puro de fuentes comestibles recicladas proporciona más trabajo de salida neta y es capaz de realizar combinaciones más prolongadas, mientras que la ventaja de mayores eficiencias térmicas que utilizan aceite lubricante reciclado se basa en su uso como aditivo en una mezcla con diesel puro. El uso de combustibles puros alternativos y ecológicos de mezclas está condicionado por los esfuerzos para producirlos y por la eficiencia térmica resultante, el trabajo de salida neta y la disponibilidad energética restante.

Palabras clave: biodiesel; aceite lubricante reciclado; eficiencia térmica; valor calorífico; disponibilidad energética 


\section{Introduction}

The population growth, industrial development, and technological breakthrough cause an increase of the energy demand, independent of its supply sources. Despite the existence of another abundant and clean energy sources, like the wind, solar, and the coming from biofuels, the fossil fuels are the most used. The main energy generation machines, like internal combustion engines, are still being developed in terms of the fossil fuels. For this reason, it is necessary to evaluate the thermal efficiency of waste substances that can be reused as alternative fuels for the existing and developed energy generation machines in order to reduce the environmental impact of the fossil fuels immediately.

Reports from 2011 to 2015 show that the fossil fuel keeps $78.36 \%$ of the global annual energy consumption. The nuclear energy registered an approximate decrease of $0.1 \%$, sharing $2.3 \%$ of the global energetic consume. The alternative fuel sources like biomass keep an average consumption of $9.06 \%$ and $0.8 \%$ of it corresponds to the biofuels exclusively used for transport. The capacity to generate the energy from the biomass from 2012 to 2016 increases from 83GW to $112 \mathrm{GW}$, registering an average growth of $7.5 \%$. The total generated energy increases from $335 \mathrm{TW}-\mathrm{h}$ in 2011 up to 504TW-h in 2016. The liquid biofuels along these 6 years of monitoring demonstrate that they are the main renewable energy supply source for transport, even counting the expansion and acceptation of the electric vehicles. The capacity of energy generation grows each year for the biomass, in comparison with the fossil fuels [1].

It is necessary to consider efficient energy generation with a balance between key aspects such as energetic, environmental and economic ones. Among the renewable energy sources, the biodiesel is considered as the most feasible cleaner fuel worldwide that can be considered as a real substitute for the diesel when its efficiency and output power are equivalent or improved compared to it. For this reason, the present research consists in evaluating of the thermal efficiency of two fuel types coming from recycled synthetic and mineral substances (such as lubrication oil) and from animal and vegetable substances (such as a used recycled edible palm oil). Four different concentrations of these fuels were studied and compared with the neat diesel under the same conditions that can occur in an engine without any changes or adjustments of engine components. This approach is performed in order to evaluate the thermal efficiency of the fuel in an isolated way, disregarding any external factor or condition that can alter the results. Thus, the conclusion and evaluation of each fuel determine its feasibility either to be an alternative or not.

The process to obtain fuels from reusable substances, such as recycled lubricating and edible oil, consists of simple distillations and transesterification processes with heterogenic catalysts, because both processes are friendly with the environment. These fuels are analyzed in a pure state and blended with neat diesel as well.

The fuels from recycled lubricating oil have a mineral and synthetic origin. This kind of substances was already used as a heavy fuel oil substitute showing advantages like better ignition quality and less smoke [2]. In the present research, the recycled lubricating oil was prepared due to three simple distillations, proving that the density value between the third and further distillations remains without any change and that the blending by agitation with neat diesel 
remains stable, even under effect of external factors like conserving time, sunlight, ambient temperature and pressure.

The fuels from recycled edible palm oil are obtained by the transesterification process with methanol and heterogenic catalysts like calcium oxide $(\mathrm{CaO})$, because of its reusability, less water requirement during the obtaining process and easier separation of the glycerol and methyl esters [3]. Furthermore, the resulting methyl esters are more volatile compared with the resulting esters from the transesterification process with ethanol. The selection of methanol is based on its ability as reagent and its economy; however, it is more toxic and comes from non-renewable sources compared with ethanol, that can be obtained from starchy or sucrose sources [4].

The use of biofuels from vegetal origin has the advantage of being renewables, biodegradable and having similar properties and characteristics like the neat diesel. The resulting pollutant emissions are significantly lower, excepting the nitrogen oxides (NOx). It is reported an increased fuel consumption, as well the reduced thermal efficiency because of its lower heat capacity [5], except the case when the lubricating oil used as a fuel blended with diesel, the heat value is higher than the diesel in a pure state [2]. According to similar researches, the reduced efficiency is more evident with an increase of a biodiesel concentration in a blend with neat diesel [6]. However, the investigation of Liu H., et al. [7], shows that the use of the neat biodiesel gives higher thermal indicated efficiency, at high engine loads; but lower at low engine loads, respectively.

The thermal efficiency is also known as the energetic efficiency that results from the ratio between the net output work produced in a thermodynamic system and the supplied heat into it coming from an external source [8]. In the present research the thermodynamic system for evaluation of the thermal efficiency is the engine; the produced net output work comes from the chemical energy conversion into calorific from the studied fuels; and the supplied heat to the system consists of the product between the fuel quantity and its lower heat value (Eq. 1).

$$
\eta_{\text {therm }}=\frac{W_{i}}{m_{f} \times H_{u f}}
$$

The points to be observed to evaluate the thermal efficiency of alternative fuels are the exactitude to quantify the heat value of each fuel type and the calculation method for the thermal efficiency. The engine test with a biodiesel from a vegetable source (in a pure state as blended as well) showed the power and the thermal efficiencies similar and close to those that can be obtained with a neat diesel; but not higher than it. To this fact, it is necessary to mention that a simplification and generalization of different blends and sources of the biodiesel are studied as a single one, with a heat value of $37 \mathrm{MJ} / \mathrm{kg}$ compared with the $42.7 \mathrm{MJ} / \mathrm{kg}$ of the neat diesel [9]. Other researchers consider a range between 39 and $41 \mathrm{MJ} / \mathrm{kg}$ for biodiesel and a higher value that amounts up to $43 \mathrm{MJ} / \mathrm{kg}$ for diesel [10].

One of the limitations for a calculation with a high level of exactitude is the absence of experimental measurements of thermodynamic properties of the fuel blends, under pressure values around 60 bar and temperature around $970 \mathrm{~K}$, which corresponds to the engine operating conditions at the end of the compression stroke. However, the reference specific heat value for diesel, recycled edible palm oil and recycled lubricating oil (all in pure states) corresponds to 2.1 $\mathrm{kJ} / \mathrm{kg} \mathrm{K}[11,12,13]$, that is a value measured between 20 and $30^{\circ} \mathrm{C}$, which is in the range to the 
feed fuel temperature according to the studied engine [14].

The importance of this research consists in a more exact method to calculate the net output work of an engine and the thermal efficiency, depending on the air and properties of each fuel type along all engine strokes, and on the engine operating conditions, as well. This method can be applied independently of the engine type and size.

The thermal efficiency is evaluated by the first law of thermodynamics considering the net output work and the heat value of the fuel; as well as evaluation of the losses inherent to the combustion and the exhaust processes, by means of the second law of thermodynamics. The advantage of this approach is in identifying and locating of the factors, causes and effects of energetic losses that affect the thermal efficiency.

Thereby, the thermal efficiency can be understood as a fact of obtaining of the maximum available net output work for each unit of fuel mass that was totally burned. However, it does not mean that the net output work can be increased in comparison with other fuels, understanding the net output work as the energy generated in the system by the fuel. Due to this approach, is possible to demonstrate that a fuel, which is able to give more net output work, is not necessarily a more thermal efficient one.

The goal of the present research consists in determining of the neat output work, the thermal efficiency and energy availability, known as the ideal additional net output work that the engine could perform when it passes to an inactive state. The evaluation of these parameters takes place with the use of different concentrations of fuels from different sources, in function of their heat values, air intake conditions and its changes during the combustion process, compression, expansion and exhaust strokes of the engine.

\section{Materials and Methods}

\section{Fuel properties}

With the characterization of the neat diesel and different concentration of fuel blends from synthetic and mineral sources as recycled fuel lubricating oil, and from animal and vegetable source as used recycled edible palm oil, was possible to get the exact experimentally measured values of the heat values of each type of the studied fuels. The meticulous analysis of each fuel sample allows to eliminate the uncertainty that implicates the assumption of a simplified and generic heat value for a certain fuel coming from a determined source, concentration and obtaining process. Thus, it is possible to evaluate the thermal efficiency exactly and to select properly the fuel type that is thermally more efficient and gives more net output work or define those fuels, which have or not any substantial difference between them.

The approximated values to produce $100 \mathrm{~kg}$ of biodiesel from recycled vegetable oil amounts $870000 \mathrm{KJ}$, while the energy content in the produced biodiesel amounts $3700000 \mathrm{~kJ}$; so the energy gain is 4 times higher [15] that means at least $25 \%$ of biodiesel in a fuel blends must be used in order to avoid any unprofitable economic and energy balance. Based on it, the studied fuels consist of $25 \%$ and $100 \%$ of the recycled edible oils blended with neat diesel, as well as the 
same proportion for the recycled lubricating oil in order to have the same comparison pattern.

Table 1. Heat Values.

\begin{tabular}{lc}
\hline \multicolumn{1}{c}{ Fuel Type } & $\begin{array}{c}\text { Heat value } \\
{[\mathrm{kJ} / \mathrm{kg}]}\end{array}$ \\
\hline D100 & 42781.7 \\
$100 \%$ Diesel & 39925.4 \\
B100 & \\
$100 \%$ Methyl ester of recycled edible palm oil & 41780.4 \\
L100 & \\
$100 \%$ Distilled of recycled lubricating oil (L100) & 42845.3 \\
B25 & \\
$25 \%$ Methyl ester of recycled edible palm oil and 75\% diesel & 42518.9 \\
L25 & \\
$25 \%$ Distilled of recycled lubricating oil and 75\% diesel & \\
\hline
\end{tabular}

Experimental measured heat value of each fuel blend. Source: Authors

The general formula of the type $\mathrm{CnH}(2 \mathrm{n}+2)$ for dodecane and hexadecane and $\mathrm{CnH}(\mathrm{n}+2) \mathrm{O}$ for fatty acid methyl esters represent the formulas for diesel, lubricating oil, and biodiesel from vegetable edible oil, respectively. In the case of the fuel blends, the atom numbers of carbon, hydrogen, and oxygen, is determined by the concentration of each component of the blend. With the general formula of each fuel type, the mole number and molecular mass of the reagents and products can be calculated. These inputs are required to complete the calculation of the enthalpies (Eq. 6) and an exact air-fuel ratio of each fuel type.

The proposed methodology to calculate the thermal efficiency, the net output network and the energetic availability allows to perform this task independent of the engine size and application. The present calculation is based on the diesel cycle and on the standard air, where the working fluid along the whole cycle is diesel. The combustion process is replaced by the heat transfer from an external source, like the energy corresponding to the heat value of the fuel. The processes are reversible and the specific heat capacities are constant. The present method can be applied to any engine and any fuel that performs the diesel cycle.

The required data of the engine for the calculation is air intake pressure, temperature, fuel feed temperature and compression ratio. The values from a diesel generator engine [14] are used as a reference for the calculations.

Table 2. Engine parameters.

\begin{tabular}{lc}
\hline Air intake pressure into the cylinder [bar] & 1.7 \\
Air intake temperature $\left[{ }^{\circ} \mathrm{C}\right]$ & 25 \\
Fuel feed temperature $\left[{ }^{\circ} \mathrm{C}\right]$ & 30 \\
Compression ratio of the engine $[-]$ & 16.5 \\
\hline
\end{tabular}

Initial data for the air properties calculation in each stroke of the cycle with each fuel type. Reference data for diesel engine generators [14]. 
Table 3. Stoichiometric equations and properties of each fuel blends.

Fuel Type

Stoichiometric equation

$$
\begin{array}{ll}
\mathrm{C}_{12} \mathrm{H}_{26}+18.5 \mathrm{O}_{2}+69.56 \mathrm{~N}_{2}=13 \mathrm{H}_{2} \mathrm{O}+12 \\
\hline \text { Air mole number } & 88.06 \\
\text { Products mole } & 94.56 \\
\text { Fuel molar mass } & 170 \\
\text { Air molar mass } & 28.970 \\
\text { Products molar mass } & 28.656 \\
\text { Air fuel ratio } & 15.02 \\
\mathrm{C}_{17} \mathrm{H}_{34} \mathrm{O}_{2}+24.5 \mathrm{O}_{2}+92.12 \mathrm{~N}_{2}=17 \mathrm{H}_{2} \mathrm{O}+17
\end{array}
$$

D100 Fuel molar mass $\quad 170$

Air mole number $\quad 116.62$

B100 Products mole $\quad 126.12$

Fuel molar mass $\quad 270$

Air molar mass $\quad 28.970$

Products molar mass $\quad 28.809$

Air fuel ratio $\quad 12.52$

$\mathrm{C}_{16} \mathrm{H}_{34}+24.5 \mathrm{O}_{2}+92.12 \mathrm{~N}_{2}=17 \mathrm{H}_{2} \mathrm{O}+16$

L100 Air mole number $\quad 116.62$

Products mole $\quad 125.12$

Fuel molar mass $\quad 226$

Air molar mass $\quad 28.970$

Products molar mass $\quad 28.687$

Air fuel ratio $\quad 14.96$

$\mathrm{C}_{13} \mathrm{H}_{28} \mathrm{O}+19.5 \mathrm{O}_{2}+73.32 .56 \mathrm{~N}_{2}=14 \mathrm{H}_{2} \mathrm{O}+$

Air mole number $\quad 95.2$

Products mole $\quad 100.32$

B25 Fuel molar mass 190

Air molar mass $\quad 28.970$

Products molar mass $\quad 28.678$

Air fuel ratio $\quad 14.53$

$\mathrm{C}_{13} \mathrm{H}_{28}+20 \mathrm{O}_{2}+75.2 \mathrm{~N}_{2}=14 \mathrm{H}_{2} \mathrm{O}+13 \mathrm{CO}_{2}+$

Air mole number $\quad 92.82$

Products mole $\quad 102.2$

L25 Fuel molar mass $\quad 184$

Air molar mass $\quad 28.970$

Products molar mass $\quad 28.665$

Air fuel ratio $\quad 14.62$

Stoichiometric equations, mole number, and molecular mass of reagents and products for each fuel type. Source: Authors.

\section{Mathematical Formulation}

The calculation of the thermal fuel efficiency begins defining the standard air properties during the intake process. These properties embrace the internal energy, enthalpy, absolute entropy, relative pressure and relative volume. All these properties are determined at a given air 
intake temperature [8].

The relative pressure and volumes allow to calculate pressures and volumes of the engine between the intake and compression stroke, and between the combustion and exhaust stroke as well. The values of the relative pressure are proportional to the ratio between the absolute entropy and universal gas constant, while the relative volume is proportional to the ratio between the universal gas constant, temperature, and relative pressure according to the equations below.

$$
\begin{gathered}
\left(\frac{P_{2}}{P_{1}}\right)_{S=C}=\frac{P_{r 2}}{P_{r 1}} \\
\left(\frac{V_{2}}{V_{1}}\right)_{S=C}=\frac{V_{r 2}}{V_{r 1}} \\
P_{r} \propto \frac{S}{R} \quad V_{r} \propto \frac{R \times T}{P_{r}}
\end{gathered}
$$

The air properties corresponding to the compression stroke are calculated as a function of the relative volume of the admission stroke and the compression ratio of the engine (Eq. 5).

$$
V_{r 2}=V_{r 1} \times\left(\frac{1}{r_{k}}\right)
$$

The pressure corresponding to the compression and exhaust stroke is calculated with the equation (2). The resulting value of the compression is the same value for the combustion pressure, considering the ideal diesel cycle.

The values of the air properties corresponding to the combustion process are determined by the calculated value of the enthalpy at this point.

$$
h_{3}=\frac{\frac{\left[n_{f} \times m_{f} \times C p_{f} \times\left(T_{f}-T_{f \_r e f}\right)\right]+\left[n_{a} \times m_{a} \times\left(h_{2}-h_{1}\right)\right]+\left[m_{f} \times q_{l}\right]}{n_{p}}+h_{p_{-} r e f}}{m_{p}}
$$

The relative volume 4, calculated with the Eq. 7, allows to calculate all the air properties corresponding to the exhaust stroke.

$$
V_{r 4}=V_{r 3} \times r_{k} \times \frac{T_{2}}{T_{3}}
$$

The net output work is calculated with the Eq. 8 .

$$
W_{\text {net_output }}=\left(\frac{1}{r_{a / f}} \times q_{l}\right)+u_{1}-\left[\left(1+\frac{1}{r_{a / f}}\right) \times u_{4}\right]
$$

The calculated thermal efficiency of the present research (Eq. 9), implies the calculated net output work (Eq. 8), the air-fuel ratio, and the lower heat value of the fuel. In comparison with Eq. 1, the difference relies on that the mass of fuel is replaced by the air-fuel ratio, but the 
net output network must be expressed in energy units per mass units of air into the engine. This approach allows to calculate the thermal efficiency in a more versatile way, based mainly on the air intake engine conditions and fuel feed temperature; instead of the necessity to determine the air flow and fuel quantity during the injection.

$$
\eta_{\text {therm }}=\frac{W_{\text {net_output }} \times r_{a / f}}{q_{l}}
$$

Finally, the energy availability of the engine with each type of fuel (Eq. 6) allows to quantify an additional ideal output work that could be obtained.

$$
-\Delta \mathcal{A}_{n / 0}=u_{4}-u_{1}-\left\{T_{1} \times\left[s_{1}-s_{4}-\left[R \times \ln \left(\frac{P_{1}}{P_{4}}\right)\right]\right]\right\}
$$

\section{Results}

The calculations with the above described equations, beside determination of the net output work and thermal efficiency of each fuel type and energy availability, allow to determine the temperature and pressure in each stroke of the engine. With the relationship between temperatures of the final of compression and the beginning of the expansion stroke, it is possible to evaluate how long the combustion process goes, and consequently to evaluate the combustion capacity of each fuel under the same conditions.

Table 4. Pewrformance and efficiency.

\begin{tabular}{lccccc}
\hline Fuel type & D100 & B100 & L100 & B25 & L25 \\
Net output work [kJ/kg] & 1538 & 1705 & 1241 & 1536 & 1622 \\
Thermal efficiency [\%] & 54.001 & 53.471 & 44.401 & 52.479 & 55.351 \\
Energetic availability [kJ/kg] & 796 & 905 & 1028 & 851 & 786 \\
$\begin{array}{l}\text { Percentage of the possible obtainable additional } \\
\text { output work [\%] }\end{array}$ & 51 & 53 & 83 & 55 & 48 \\
Ratio $\mathrm{T}_{3} / \mathrm{T}_{2}$ & 3.22 & 3.47 & 3.17 & 3.33 & 3.21 \\
\hline
\end{tabular}

Performance and efficiency properties of each fuel type. 


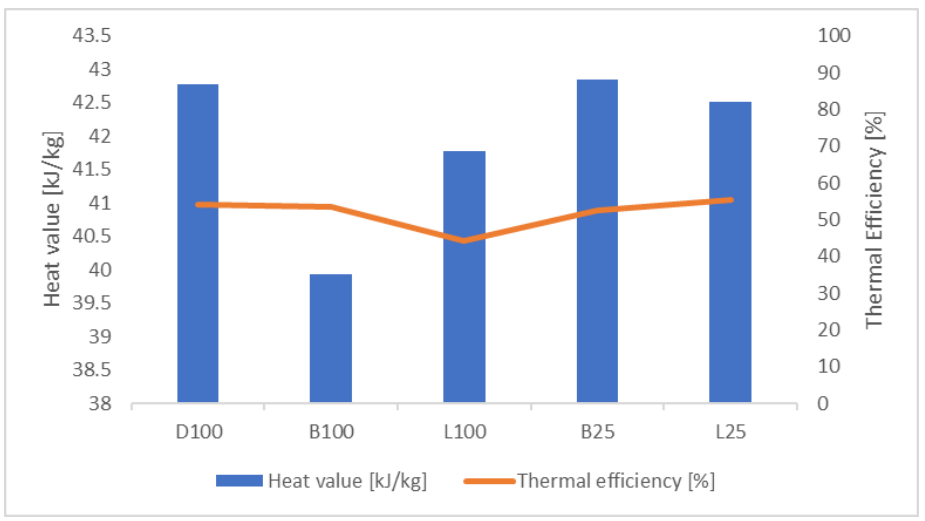

Figure 1. Comparative chart of the Thermal efficiency of each fuel type.

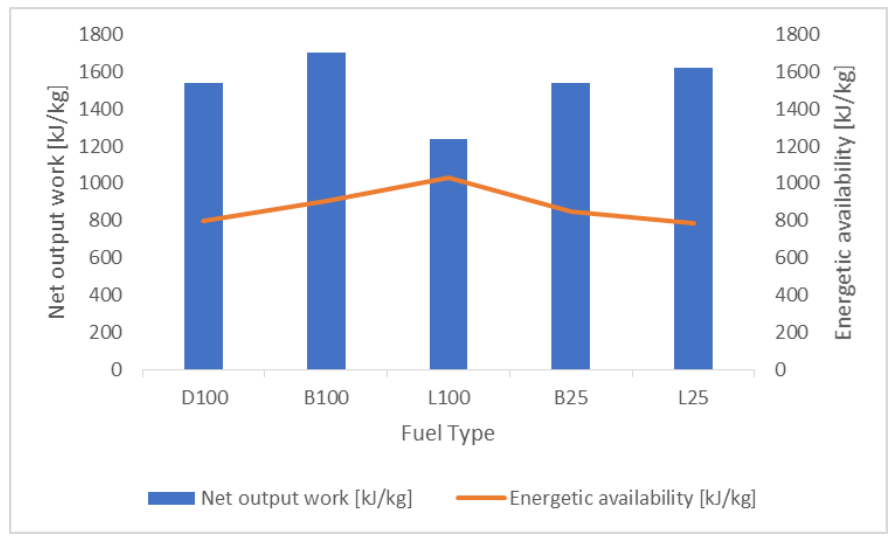

Figure 2. Comparative chart of the net output work and the energetic availability of each fuel type.

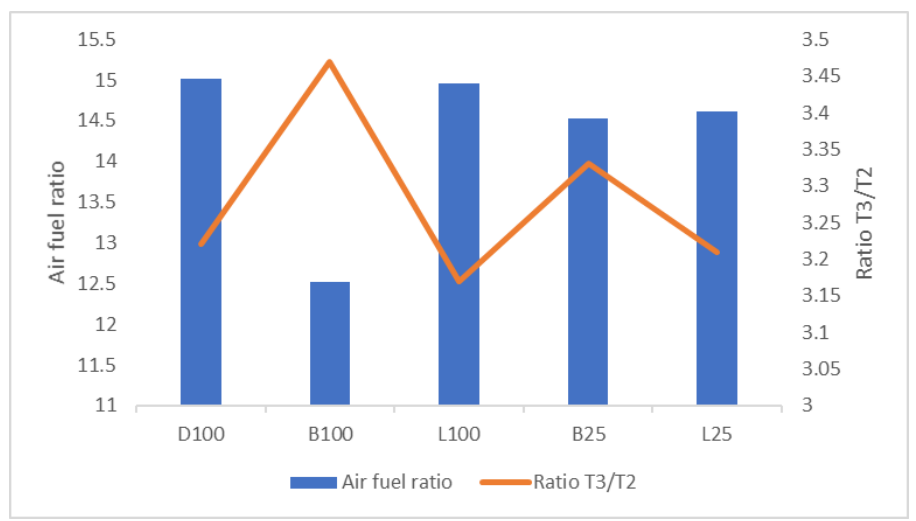

Figure 3. Comparative chart of the air-fuel ratio and the ratio T3/T2 as a measure of the combustion duration. 


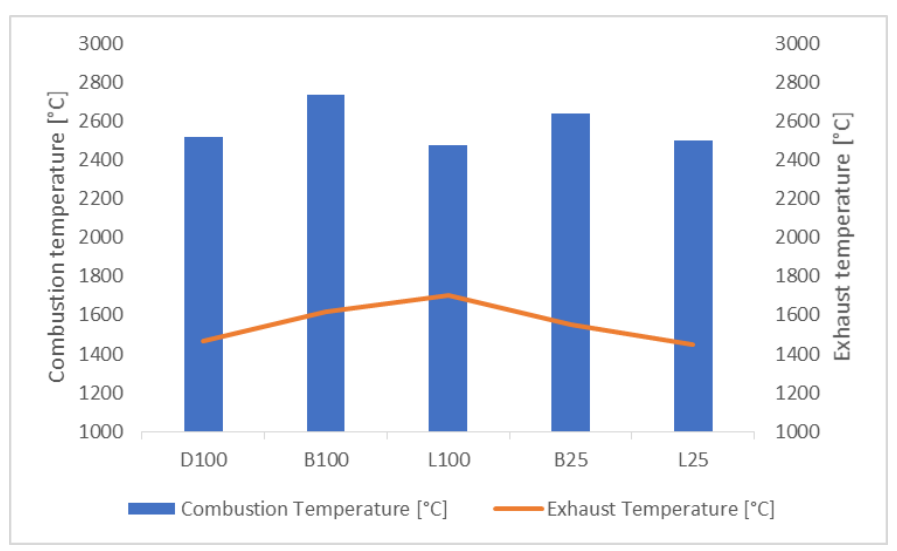

Figure 4. Comparative chart of the calculated combustion and exhaust temperatures with each fuel type.

\section{Discussion}

Despite the lower heat value of the fuel consisting of $100 \%$ biodiesel (Fig. 1), this fuel type gives more net output work, thermal efficiency is very close to the neat diesel (Fig. 2). This is explained by the higher molar concentration for the fuel and air components of the stoichiometric equations of this type of biodiesel that increases the enthalpies and internal energy at the combustion process. By means of the cutoff ratio (T3/T2), it is also observed that the combustion goes longer and consequently most of the fuel will be burned compared with other fuel types (Fig. 3), this fact also supports the experiments, in which the harmful exhaust emissions are lower with the neat biodiesel.

The fuel consisting of $100 \%$ lubricating oil has the lowest performance regarding the net output network and a big potential of the energy, which could be transformed as an additional work, is not used, as the values of the energetic availability reveal (Fig 1). However, the fuel consisting of $100 \%$ biodiesel, and the blend consisting of $25 \%$ recycled lubricating oil and $75 \%$ diesel, show the higher net output work (Fig. 1). The ratio between the combustion and the compression temperature and the exhaust temperatures as well reveal that this kind of fuel is able to perform shorter combustion processes with higher net output work and thermal efficiencies (Fig. 4).

From the stoichiometric equations (Tab. 3) and the (Fig. 3) it is observed that all the studied alternative fuels of the present research will produce an increased fuel consumption compared to the neat diesel, this effect is especially significant for the $100 \%$ biodiesel, and lower for the L25 fuel blend of recycled lubricating oil.

The fuel blend consisting of $25 \%$ recycled edible oil and $75 \%$ diesel shows results close to the neat diesel, justifying its use, as a reduction of the neat diesel consumption by $75 \%$ and increasing the use of alternative recycled substances as a fuel by $25 \%$.

The thermal efficiency of B100, B25 and particularly L25 fuel blends, are equivalent to the neat diesel, but even when this parameter remains stable, there are considerable variations regarding air-fuel ratio and the combustion duration expressed by the ratio between the 
combustion and the compression temperatures.

The use of $100 \%$ recycled lubricating oil as an alternative fuel showed poor results in all the parameters, disregarding its use as an alternative fuel in a pure state. However, its use in a fuel blend of $25 \%$ of this recycled oil type and diesel showed that it is the most efficient fuel blend. It has the lower remaining available energy, as an indicator that the most of the fuel is transformed in net output work, and has the lower calculated exhaust temperature, which means better conditions to reduce the formation of nitrogen oxides (NOx).

\section{Conclusion}

The methodology presented in this research showed a way to determine the net output work and efficiency of the fuel depending on the fuel heat value, air intake and engine operation conditions. This methodology allows to evaluate the sustainability and applicability of any fuel by a thermodynamic approach, before it can be tested in a real engine, optimizing time and resources.

Due to a thermodynamic calculation based on the engine parameters and the air properties, considered as an ideal gas, the present research demonstrates that the neat biodiesel (B100) gives more net output work, than neat diesel and other fuel blends, even under the effect of a lower heat value, but considered that all the studied fuels are injected, atomized and mixed to form a stoichiometric air-fuel mixture, compensating any variation regarding densities and viscosities, of each fuel type.

The recycling of mineral-synthetic substances, such as lubricating oil, has the potential to improve the thermal efficiency of an engine when these substances are used as an additive blended with the neat diesel, but not in a pure state. The use of this fuel type as an alternative neat fuel to substitute diesel or fuels from the vegetable-animal origin is not recommended. In the same way, the efforts to produce the biodiesel by means of transesterification and to use it as a blend in a concentration lower than $25 \%$ without any significant improvement compared to neat diesel is questionable.

By means of the present methodology to evaluate the thermal efficiency of different fuels, it is demonstrated that an increased net output network does not mean an increase in the thermal efficiency.

The available net output work and thermal efficiency of a fuel blend not only depends on its heat value, as observed in the results. The fuels with lower heat values but higher molar concentrations have a bigger energy release during the combustion process that results in higher net output work.

The fuels able to give higher efficiency values are not those with the higher net output work values because the efficiency of a fuel consists of a required energy to produce a determined net output work.

Lower cutoff ratios mean higher thermal efficiencies; while higher cutoff values represent more net output work of the engine, and consequently higher combustion temperatures that will 
produce more nitrogen oxides (NOx).

The results of the present research of the alternative fuels from recycle edible oils and form lubricating show that they are an alternative and have a chance to occupy more of $78 \%$ of the total demand of the fossil fuels.

The use of the biofuel represents a necessity in order to reduce the impact on the environment of the fossil fuels and a way to reuse mineral-synthetic, and vegetable-animal waste oil to generate net output work in a system with the less energy required for it.

\section{Definitions/Abbreviations}

$\eta$ therm: Thermal efficiency

Wi: Net output work $[\mathrm{kJ} / \mathrm{kg}]$

mf: Mass of fuel [kg]

Huf: Lower heat value of the fuel $[\mathrm{kJ} / \mathrm{kg}]$

D100: Diesel fuel

B100: Biodiesel from 100\% recycled vegetable oil

L100: Fuel from 100\% recycled lubricating oil

B25: Fuel blend from 25\% recycled vegetable - animal oil and 75\% neat diesel

L25: Fuel blend from 25\% recycled lubricating oil and 75\% neat diesel

C: Carbon

H: Hydrogen

O2: Oxygen

N2: Nitrogen

H2O: Water

CO2: Carbon dioxide

P: Pressure [ bar ]

$\mathrm{T}$ : Temperature $\left[{ }^{\circ} \mathrm{C}\right]$

Pr: Relative pressure

$\mathrm{Vr}$ : Relative volume

$\mathrm{h}$ : Enthalpy $[\mathrm{kJ} / \mathrm{kg}]$

$\mathrm{u}$ : Internal energy $[\mathrm{kJ} / \mathrm{kg}]$

S: Entropy $[\mathrm{kJ} / \mathrm{kg} \mathrm{K}]$

$\mathrm{C}$ : Constant

R: Universal air gas constant: $287.08[\mathrm{~J} / \mathrm{kg} \mathrm{K}]$

rk: Compression ratio [-]

nf: Fuel molar number [mole]

mf: Fuel molar mass [kg/mole]

Cpf: Specific heat value of the fuel $[\mathrm{kJ} / \mathrm{kg} \mathrm{K}]$

Tf: Fuel feed temperature $\left[{ }^{\circ} \mathrm{C}\right]$

Tf_ref: Fuel temperature at a reference value of $25^{\circ} \mathrm{C}\left[{ }^{\circ} \mathrm{C}\right]$

na: Air mole number [mole]

ma: Air molar mass $[\mathrm{kg} / \mathrm{mole}]$

$\mathrm{np}$ : Products mole number [mole]

mp: Products molar mass $[\mathrm{kg} / \mathrm{mole}]$

hp_ref: Reference enthalpy of the products at a reference temperature of $25^{\circ} \mathrm{C}[\mathrm{kJ} / \mathrm{kg}]$ 
Wnet_output: Net output work [kJ/kg]

$\mathrm{ra} / \mathrm{f}:$ Air fuel ratio [-]

ql: Lower heat value of the fuel $[\mathrm{kJ} / \mathrm{kg}]$

$-\triangle \mathrm{An} / 0$ : Energetic availability $[\mathrm{kJ} / \mathrm{kg}]$

Suffix: 1 = intake, 2 = compression, $3=$ combustion, $4=$ exhaust

\section{Biboliography}

REN21 Renewable Energy Policy Network for the 21st Century. "Renewables 2013, 2014, 2015, 2016, 2017 Global Status Report,” http://www.ren21.net, accessed Feb. 2018.

Tajima, H., Takasaki, K., Nakashima, M., Yanagi, J. et al., "Combustion of Used Lubricating Oil in a Diesel Engine," SAE Technical Paper 2001-01-1930, 2001, https://doi.org/10.4271/2001-01-1930

Gopal, S., Sajitha, C., "Production of biodiesel from vegetable oil using $\mathrm{CaO}$ catalyst \& analysis of its performance in four stroke diesel engine," International Journal of Scientific and Research Publications, Volume 3, Issue 11, November 2013.

Castellar, G., Angulo, E., Cardozo, B., "Transesterification vegetable oils using heterogeneous catalysts," in Spanish, Prospect, Vol 12, N², 90-104, 2014.

Xue, J., Grift, T., Hansen, A., "Effect of biodiesel on engine performances and emissions," Renewable and Sustainable Energy Reviews, 15(2011), 1098-1116, 2011, doi: 10.1016/j.rser.2010.11.016.

Hasan, M., Rahman, M., "Performance and emission characteristics of biodiesel-diesel blend and environmental and economic impacts of biodiesel production: A review", Renewable and Sustainable Energy Reviews, $74 \quad$ (2017) 938-948, 2017, https://doi.org/10.1016/j.rser.2017.03.045

Liu, H., Ma, X., Li, B., Chen, L., Wang, Z., Wang, J., "Combustion and emission characteristics of a direct injection diesel engine fueled with biodiesel and PODE/biodiesel fuel blends," Fuel, 209 (2017) 62-68, 2017, http://dx.doi.org/10.1016/j.fuel.2017.07.066

Faires, V., Simmang C. M. "Thermodynamics, 6th edition," (Macmillan), 1978, ISBN: $0029789109,9780029789100$.

Rakopoulos, C., Antonopoulos, K., Rakopoulos, D., Hountalas, D., Giakoumis, E., "Comparative performance and emissions study of a direct injection Diesel engine using blends of Diesel fuel with vegetable oils or bio-diesels of various origins". Energy Conversion and Management, 47 (2006) 3272-3287, 2006, doi: 10.1016/j.enconman.2006.01.006.

Mahmudul, H., Hagos, F., Mamat, R., Abdul Adam, A., Ishak, W., Alnezi, R., "Production, characterization and performance of biodiesel as an alternative fuel in diesel engines - A review," Renewable and Sustainable Energy Reviews 72 (2017) 497-509, 2017, doi: 
http://dx.doi.org/10.1016/j.rser.2017.01.001

Cengel, Y., Boles, M., “Thermodynamics. An Engineering Approach, 7th edition,” (McGraw Hill), 2010, ISBN: 0077366743, 978-0077366742.

Narvaez, P., Rincon, S., Castaneda, L., Sanchez, F., "Determination of some physical and transport properties of palm oil and of its methyl esters," Latin American Applied Research, 38:1-6 (2008), 2008.

Wrenik, S., Sutor, P., Pangilinan, H., Schwarz, E., "Heat transfer properties of engine oils," Proceedings of WTC2005 World Tribology Congress III, 2005.

MTU Friedrichshafen, "Operating Instructions Diesel engine 16 V 4000 E20,", "Diesel Generator Set MTU 16V4000 DS2250” https://www.mtu-online.com, accessed Feb. 2018.

Vidal, A., Quintero, J., Herrera, I., "Life cycle analysis of biodiesel from used vegetal oil," in Spanish, DYNA 84(201), pp. 155-162, 2017, doi: http://dx.doi.org/10.15446/dyna.v84n201.54469.

\section{Appendix}

Appendix 1. Air properties, temperatures, and pressures in each engine stroke / process and with each full type.

\begin{tabular}{|c|c|c|c|c|c|c|c|c|}
\hline Fuel Type & $\begin{array}{r}\text { D100, } \\
\text { B25 }\end{array}$ & $\begin{array}{l}\text { B100, L100, } \\
\text {, L25 }\end{array}$ & & 100 & & 100 & & 100 \\
\hline 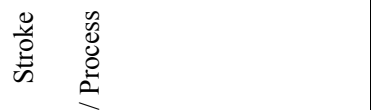 & 荡 & 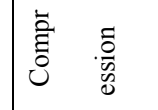 & हี & 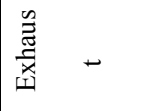 & है है & 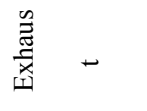 & 予 & 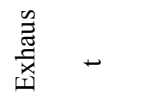 \\
\hline Enthalpy $[\mathrm{kJ} / \mathrm{kg}]$ & 297.961 & 896.502 & 3259.185 & 1926.465 & 3535.171 & 2113.082 & 3205.732 & 2221.602 \\
\hline Relative pressure & 1.359 & 65.215 & 9140.664 & 1167.107 & 13467.328 & 1649.351 & 8519.438 & 1991.128 \\
\hline Internal energy $[\mathrm{kJ} / \mathrm{kg}]$ & 212.899 & 647.53 & 2457.658 & 1427.877 & 2672.51 & 1571.188 & 2416.132 & 1654.654 \\
\hline Relative volume & 146.34 & 8.869 & 0.207 & 1.06 & 0.169 & 0.804 & 0.126 & 0.656 \\
\hline Entropy function $[\mathrm{kJ} / \mathrm{kg} * \mathrm{~K}]$ & 2.51 & 3.621 & 5.036 & 4.435 & 5.126 & 4.539 & 5.017 & 4.596 \\
\hline $\begin{array}{l}\text { Temperature in each point of } \\
\text { the stroke / process }\left[{ }^{\circ} \mathrm{C}\right]\end{array}$ & 25 & 594 & 2520 & 1464 & 2733 & 1615 & 2478 & 1702 \\
\hline $\begin{array}{l}\text { Pressure in each point of the } \\
\text { stroke / process [bar] }\end{array}$ & 1.7 & 81.561 & 81.561 & 10.414 & 81.561 & 9.989 & 81.561 & 19.092 \\
\hline \multicolumn{2}{|l|}{ Fuel Type } & \multicolumn{2}{|c|}{ D100, B100, L100, B25, L25 } & \multicolumn{3}{|c|}{ B25 } & \multicolumn{2}{|c|}{$\mathbf{L 2 5}$} \\
\hline
\end{tabular}




\begin{tabular}{|c|c|c|c|c|c|c|}
\hline 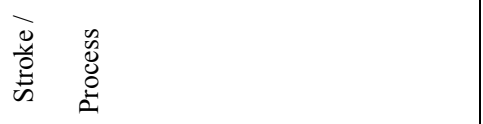 & 节 & 芯 & 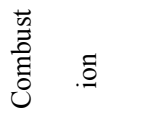 & 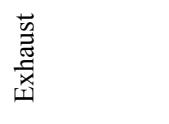 & 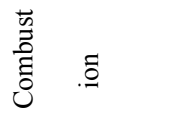 & 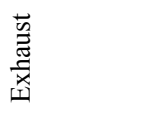 \\
\hline Enthalpy $[\mathrm{kJ} / \mathrm{kg}]$ & 297.961 & 896.502 & 3415.057 & 2035.217 & 3231.572 & 1906.146 \\
\hline Relative pressure & 1.359 & 65.215 & 11584.28 & 1448.138 & 8760.192 & 1114.601 \\
\hline Internal energy $[\mathrm{kJ} / \mathrm{kg}]$ & 212.899 & 647.53 & 2579.002 & 1511.393 & 2436.09 & 1412.274 \\
\hline Relative volume & 146.34 & 8.869 & 0.185 & 0.911 & 0.211 & 1.088 \\
\hline Entropy function $\left[\mathrm{kJ} / \mathrm{kg}^{*} \mathrm{~K}\right]$ & 2.51 & 3.621 & 5.087 & 4.496 & 5.027 & 4.449 \\
\hline $\begin{array}{l}\text { Temperature in each point of the stroke } \\
\text { / process }\left[{ }^{\circ} \mathrm{C}\right]\end{array}$ & 25 & 594 & 2640 & 1552 & 2498 & 1448 \\
\hline $\begin{array}{l}\text { Pressure in each point of the stroke / } \\
\text { process [bar] }\end{array}$ & 1.7 & 81.561 & 81.561 & 10.196 & 81.561 & 10.377 \\
\hline
\end{tabular}

